\title{
IS PRESIDENT DONALD TRUMP'S CURRENT TRADE POLICY A REAL THREAT TO INTERNATIONALTRADE ORDER? LEGAL AND POLICY ASSESMENT
}

\author{
Piotr KOBIELSKI ${ }^{1}$ \\ The Military University of Technology
}

\begin{abstract}
The purpose of this article is to answer the question whether the current trade policy of the President Donald Trump's administration, aimed at greater protectionism and isolationism in international trade, may result in undermining or even dismantling international trade order as we know it for the last several decades. Taking into account unfolding trade war between the United States and the People's Republic of China special focus is given to potential new trade war between the US and the European Union. In order to narrow the scope of the paper's analysis and to best illustrate the prospect of the EU-US trade war special attention is given to historical and current trade disputes between both parties over agri-food products, including hormone-treated beef, bananas, GMOs, poultry meat treated with bactericidal substances, Spanish olives and American soybeans. In conclusion of this paper it is explained that due to several reasons the new US-EU trade war is highly unlikely. This said it is also concluded that current stance in international trade taken by the White House, although very controversial and openly confrontational, poses no real threat to modern international trade order. Keywords: international trade, trade war, dispute, tariffs, President Donald Trump, United States, European Union, the People's Republic of China, World Trade Organization, conservatism, agri-food products.
\end{abstract}

\section{Introductory remarks}

The purpose of this article is to answer the question whether the current trade policy of the administration of President Donald Trump, aimed at greater protectionism and isolationism in international trade, may result in undermining or even dismantling international trade order as we know it for the last several decades of its formation. Is it likely that the new trade war with the People's Republic of China (PRC) and creeping disputes with the US traditional trade partners, such as Canada, Mexico and the EU, would undermine the stability and prosperity of the world economy. Or, sharing the US opinion, maybe the allegedly hostile actions taken by the US administration should be rather seen as justified and necessary attempt to correct obvious imbalances in international trade, kept unchanged to an obvious disadvantage of the world biggest economy - the US. Current turbulences in

1 Piotr Kobielski holds Ph.D. in international law (Warsaw University). He is also a former fellow at Harvard University (2012-2013). Currently he is an Assistant Professor at the Military University of Technology. All views reflected in the present paper are his private ones and they do not reflect the views of any organization he is affiliated with. 
international trade lead to the conclusion that special attention to such megatrends in international politics should be given not only in economic but most of all in security studies. It is due to the fact that economic instability is one of the main factor and common precondition of many international military disputes. Its scientific examination must be reflected in a core rather than peripheries of security studies.

In the following pages thorough analysis of current attitudes of the President Donald Trump's administration towards international trade agreements, such as the World Trade Organization (WTO) and the North American Free Trade Agreement (NAFTA), as well as trade relations with the PRC is provided. Taking into account an unfolding trade war between the US and the PRC special focus is given to potential trade dispute with the EU as the biggest in the world open and democratic single market of 500000000 consumers. It is argued that evolution of such a dispute into an open trade war may not only inflame already unstable world economic affairs but most of all destroy historic Transatlantic community of free and democratic nations forever. It may lead to the point where there will be no return to bilateral cordial cooperation in variety of fields - from commerce to security. In order to narrow the scope of analysis and to best illustrate the prospect of the EU-US trade war special attention is given to historic and current trade disputes between US and EU over agri-food products as the most important trade commodities. Its analysis would help to conclude on the main question of this paper - is current trade policy of President D. Trump a real threat to international trade order. Thorough examination of policy and legal measures taken by both - the US and the EU, would facilitate such conclusion.

\section{Trade Doctrine of the President D. Trump's Administration}

\subsection{International trade doctrine}

The current policy of the White House concerning international trade is implementation of the President's election promises of 2016 and specifically the implementation of the "America-First" and "Make-America-Great-Again" election slogans. Right after the presidential elections the US decided to freeze negotiations on the Transatlantic Trade and Investment Partnership (TTIP), pull out of the Trans-Pacific Partnership(TPP $)^{2}$ and revise the NAFTA. Examining the reasons of such a position, it should be pointed out that the views of President D. Trump on international trade do not reflect classic American conservatism in economic matters. One of the most traditional varieties of American conservatism, the so-called "principled conservatism" presupposes an attachment to such principles as personal freedom, freedom of

2 US may in fact rejoin TPP as announced by President D. Trump in April 2018. See: A. Swanson, Trump Proposes Rejoining Trans-Pacific Partnership, „The New York Times”, 12 April 2018. 
enterprise and the limited role of central government. ${ }^{3}$ In light of these principles, tariffs and other restrictions in international trade artificially and unjustifiably limit economic freedom. Their introduction undermines the very essence of freedom of every man and woman. Nevertheless, the actions of President D. Trump, declaring himself as a conservative politician, do not reflect the principles of classical American conservatism in the economic sphere. To the contrary, they are similar to traditional American economic isolationism and protectionism of the 1920s and 1930s. Their aim is to protect the domestic market while forcefully attempting to gain broader access to third-country markets for American products.

\subsection{World Trade Organization}

Another aspect of the international trade policy of the President D. Trump's administration is instrumental treatment of international economic and commercial institutions such as the World Trade Organization (WTO). The President is often portrayed in media as a fierce enemy of international trade order having personal disregard to its inherited rules. Still, the administration of D. Trump does not undermine the essence of the WTO institutional system, but nevertheless threatens to dismantle it in the face of failure to meet an American demands on selected subject matters and geographical directions. At the end of August 2018 President D. Trump announced the prospect of leaving the WTO, unless the organization is reformed (to quote after the President's interview for Bloomberg - "If they do not 'shape up', I would withdraw from the WTO"). ${ }^{4}$ According to one analysts such action won't succeed, "[t]he prospects of an American exit are slim, as it would require the approval of Congress". ${ }^{5}$ Opinion on staying within the world's super-trade block seems also to predominate in actions taken by the US Trade Representative, Robert Lighthizer, "whose influence in the White House is in stark contrast to his low profile outside it". ${ }^{6}$ According to his own words the WTO does "an enormous amount of good". ' At the same time, the US is blocking the appointment of new judges to the so-called Appellate Body ( $\mathrm{AB})$, an appellate instance settling commercial disputes after the first instance panels. As of the end of August 2018 only 3 out of 7 posts in the AB were occupied. Such obstructive US policy within the WTO should be seen as an attempt to enforce a more strict policy by this organization against the biggest American competitors in international trade, and especially towards the

3 A. Bramwell, What is Principled Conservatism?, "American Affairs", Spring 2018, vol. II, no. I, p. 142.

4 J. Micklethwait, M. Talev, J. Jacobs, Trump threatens to pull U.S. out of WTO if it doesn't 'shape up', Bloomberg.com, 30 August 2018.

5 Trade blockage, “The Economist”, 21-27 July 2018, p. 15.

6 Ibidem, p. 16.

7 Ibidem. 
PRC, which has a significantly positive trade balance in relations with the US. ${ }^{8}$ Thus, by blocking new judges' appointments and threatening to leave the WTO, the US does not make a direct accusation against the internal WTO organization but pursuing its trade policy. Any institutional changes there will be secondary to the implementation of the main US demand - liquidation of the US negative trade balance through less lenient policy towards the PRC. This conclusion steams also from the fact that dangers of the PRC's trouble-making at the WTO level lurked on the horizon far earlier than the President's appointment for his office. ${ }^{9}$ So far, the internal organization of the WTO, and in particular the dispute resolution methods, did not raise any major reservations on the part of the US, contrary to the nature and real-life economic issues behind these disputes (eg. the correct assessment by the WTO and its panels of the Chinese anti-dumping practices). In addition it must be reminded that US trade negotiators have always been regarded in the "Geneva bubble" as perfectly-prepared and very effective in trade disputes before the WTO. Consequently, while the WTO dispute settlement system will serve US commercial interests, the US will never advocate its liquidation. On the other hand, simply speaking, if current trade demands of the US are not meet this could be the end of the post-World War II economic system that the US helped to build. ${ }^{10}$

\subsection{The North American Free Trade Agreement}

The prime example of an attachment of the Presidents D. Trump's administration to international trade institutions is renegotiating process of the NAFTA. In the course of negotiations with Mexico and Canada, the US did not intend to renegotiate the method of solving investment disputes within this block. As a result of reaching an agreement with Mexico, a number of mutual economic interests regarding agri-food products have been secured. In particular, zero tariffs for agri-food products were maintained, new standards in the field of biotechnology (GMOs) were set, new commitments to eliminate free trade barriers were agreed, a ban on discrimination against products from both countries was guaranteed, new rules on scientific basis for sanitary and phytosanitary requirements were introduced as well as existing discrepancies between the US and Mexico concerning the geographical labeling of products, including the recognition of spirit products, were eliminated (eg. Bourbon Whiskey and Tennessee Whiskey were recognized as American products, while Tequila and Mezcal were recognized as Mexican products). ${ }^{11}$ As a consequence,

A plan to save the WTO, "The Economist", 21-27 July 2018, p. 7.

$9 \mathrm{M}$. Wu, The 'China Inc.' Challenge to Trade Governance, "Harvard International Law Journal", Spring 2016, vol. 57, no. 2, p. 261 and the following.

10 J. Micklethwait, op. cit.

11 United States-Mexico Trade Fact Sheet. Strengthening North American Trade in Agriculture, US Trade Representative's Fact Sheet, 31 August 2018. 
signing of the US-Mexican agreement does not undermine the existing institutional order of the NAFTA. It does not threaten its existence since it will be used in favor of American investors against Mexico in future bilateral commercial disputes.

\subsection{Internal trade doctrine}

Quite contrary to the views on international trade President D. Trump manifests his positive attitude towards internal trade, where the classic principles of American economic conservatism clearly prevail. President $\mathrm{D}$. Trump himself is an avid supporter of abolishing all regulatory restrictions on internal market, the so-called "red tape", "a hidden tax on consumers" and the "job-killing industry". Actions taken in this respect are among the most ambitious in recent years. ${ }^{12}$

\section{US Trade Disputes over Agri-Food Products}

\subsection{Trade war with the People's Republic of China}

So far, the weight of the President D. Trump's hostile approach to international trade has concentrated on US-PRC relations. The cost of trade war waged by the US has already exceeded USD 200 billions Chinese imports to the US. Relatively small attention is given by the current administration to other trade regions, including the UE. Moreover trade measures introduced by the US administration to protect the American market from selected products of third countries only to a small extent include agri-food products. The most multilateral US trade measure aimed at several third countries (India, Turkey, Germany, Canada and the like) concerned foreign steel. The US commercial administration, under direct instructions of President D. Trump, in at least three subsequent waves raised tariffs on different Chinese product categories:

- In April 2018 President D. Trump announced the increase of duties on more than 1,300 various types of products imported into the US from the PRC. In response, the PRC decided to increase by $25 \%$ its tariff on soybeans imported from the US. Until that moment the PRC was the recipient of $50 \%$ of the production of American soybeans, market worth more than USD 14 billion. The PRC's strike against US soybeans producers was not only economic in nature but most of all political one - the Midwest states in the last US presidential elections supported D. Trump's candidacy. The Chinese also threatened retaliation against American maize, beef, wheat and cotton.

12 J. Postell, Regulation in Early America, “American Affairs”, Spring 2018, vol. II, no. I, p. 87 and 88. 
- Having above in mind in July 2018 US Trade Representative R. Lighthizer issued a statement on agriculture assistance against illegal trade retaliation. According to the wordingof the statement "President Trump is taking strong action, as he promised, to make sure America's farmers and ranchers are not left to bear the brunt of illegal retaliation by China and other countries". ${ }^{13}$

- In June 2018, following the President D. Trump's direct instruction of May 2018, a new list of customs duties on more than 1,100 Chinese product categories of USD 50 billion was announced. The implementation of the new tariffs was two-stage - firstly, the US introduced tariffs on 818 product categories worth USD 34 billion, and then on another 284 categories worth USD 16 billion. ${ }^{14}$

- In July 2018 the US administration identified approximately 6,000 Chinese product categories, worth USD 200 billion, with the intention of taxing it. The amount of new duties at the time of their introduction, i.e. 24 September 2018, was 10\%. From 1 January 2019 they will increase to $25 \%$. It is estimated that the Chinese GDP in the result of US cumulative trade measures will shrink by $0.3 \%{ }^{15}$

US trade measures against Chinese products resulted in retaliation measures introduced by the PRC, including against agri-food products imported from the US. Yet current dispute with the PRC over variety of products is not historically the first US-China commercial dispute. However, in sharp contrast to the previous disputes, this time the US decided not to settle it through the existing mechanisms of international trade system, i.e. through the WTO, but to omit it in order to directly confront itself with the PRC. US administration, probably for the first time in the last three decades, decided intentionally to circumvent the long-lasting legal proceedings and back its unilateral action with its economic strength. This does not necessarily mean to pose a direct threat to international trade order but rather to choose more suitable and effective measure, at least in the US opinion, aimed at swift result.

\subsection{Historical US trade disputes with the EU}

The EU and the US have a long-lasting and rich history of trade disputes over its agri-food products. Thorough examination of historical cases between the two parties, including the disputes before the WTO, may lead to a conclusion that in the

13 USTR Robert Lighthizer Statement on Agriculture Assistance Against Illegal Trade Retaliation, US Trade Representative's Press Release, 24 July 2018.

14 USTR Issues Tariffs on Chinese Products in Response to Unfair Trade Practices, US Trade Representative's Press Release, 15 June 2018.

15 USTR Finalizes Tariffs on \$200 Billion of Chinese Imports in Response to China’s Unfair Trade Practices, US Trade Representative's Press Release, 17 September 2018. See also: China Urges U.S. to Make 'Right Decision' as \$200B Tariffs Near, Bloomberg.com, 30 August 2018. 
nearest future agri-food products could cause major risk to bilateral trade relations and thus to international trade order as a whole. Below a non-exhaustive list of the most important agricultural disputes between the US and the EU is provided for better understanding of current state of affairs:

\section{i. $\quad$ Hormone-treated beef(1989-2012)}

In 1989 the European Economic Community (EEC), in accordance with the Council Directive 88/146/EEC of 7 March 1988 prohibiting the use in livestock farming of certain substances having a hormonal action, introduced the prohibition of the use of certain hormonal compounds in cattle breeding. This was tantamount to a total ban on an import of American hormone-treated beef to the EEC. The ban included 6 hormone compounds used in breeding in the US. In the same year the US imposed retaliatory tariffs of $100 \%$ on selected EU food products. In January 1996 the US requested consultations before the WTO regarding the introduction of the ban. In 1997 the WTO panel settled the dispute to the detriment of the EU. According to the panel's report the ban on the import of American beef violated the WTO Agreement on the application of sanitary and phytosanitary measures (the SPS Agreement), because it was supported by the sufficient scientific research. In implementing this decision the EU carried out adequate scientific research, while maintaining the ban on American imports. In 1999, after the expiration of previous retaliatory tariffs, the US decided to re-introduce them on selected EU products. In October 2008, the WTO again settled the case, this time sharing the arguments of both parties - confirming the EU's right to maintain the ban and the US's right to maintain retaliatory tariffs against the EU. In May 2009, the EU and the US concluded the Memorandum of Understanding, which was subsequently reviewed by the parties. As a result of talks, the EU allowed imports of American free-of-growth-hormones beef to its market, while the US significantly reduced the retaliation tariffs for EU products. Although both sides continue to support their position regarding the legitimacy of using growth hormones in slaughterhouse cattle breeding, from 2012 the present dispute can be considered as finally settled due to the opening of the EU market to the US high-quality beef and the abolition of retaliatory tariffs by the US. ${ }^{16}$ Currently both parties negotiate to widen the quotas for the US high-quality beef. In order to serve the higher purpose of avoiding open trade war between the EU and the US, and thus to preserve the principles of international trade order, the EU will most likely agree for higher US beef quotas. ${ }^{17}$

16 The transatlantic trade dispute on "hormones" in beef comes to an end, Council of the EU, 9178/12 PRESSE 171, 26 April 2012.

17 E. Livingstone, POLITICO Pro Morning Agri and Food, POLITICO.eu, 24 September 2018. 


\section{ii. Bananas (1993-2009)}

The conflict over imports of bananas into the EU was one of the longest between the EU and the US joined by other Latin American countries. Bananas are the most popular fruit of the world with around 130 million tonnes produced annually. Bananas are also the most internationally sold fruit, the global banana export is equivalent to EUR 7 billion. $30 \%$ of global exports goes to the EU, where the banana market is valued at around EUR 2 billion. Top 4 US producers, who grow the so-called "dollar banana" in South America, are responsible for $70 \%$ of bananas imported into the EU. The remaining share in the European market belongs to the so-called "ACP banana" (Africa, Caribbean, Pacific) produced in former French and British colonies as well as to domestic EU production (i.e. heavily subsidized banana production in the Canary Islands). In 1993, the US and the Latin American countries submitted to the WTO a number of complaints about the EU tariffs on dollar bananas (they amounted to EUR 176 for each ton of bananas). In 2009, the parties to the dispute reached a compromise under which from 1 January 2017 bananas tariffs were reduced by $30 \%{ }^{18}$

\section{iii. GMOs (2003-2008)}

Another on the long list of the US-EU trade disputes was the one related to genetically modified organisms (GMOs). In 2003, the US launched a case against the EU before the WTO to protect US specific biochemical products, namely products resulting from genetic modifications. The case was registered under the reference no. DS291. Similar complaints against the EU were filed by Canada and Argentina. The US accused the EU of introducing in 1998 a de facto moratorium on conducting internal procedures for the admission of certain biochemical products to the EU market from outside. The EU de facto moratorium effectively prevented any imports of this type of American biochemical products to the EU. Simultaneously the US accused the EU of allowing its individual member states to maintain national bans on the import and sale of GMOs, regardless of relevant legislation at the EU level. In 2006 the WTO panel shared arguments of the US and confirmed the existence of a de facto moratorium on internal proceedings within the EU. Solutions applied in individual member states were also criticized by the WTO. Finally, in 2008, both parties agreed to implement the findings of the WTO panel bringing the dispute to its end. ${ }^{19}$

18 Banana Market Review and Banana Statistics 2012-2013, Food and Agriculture Organization of the UN, Rome 2014. See also: Agriculture in the Canaries is completely bananas, France24.com, 26 December 2016.

19 EU GMO ban was illegal, WTO rules, Euractive.com, 12 May 2006. 


\subsection{Current US trade disputes with the EU}

i. $\quad$ Poultry (1997-currently)

According to the SPS Agreement any state action to protect human, animal and plant health must be supported by scientific research and therefore it cannot be arbitrary or discriminatory. The EU-US dispute over poultry is another example of a completely different understanding of the scientific basis in food risk assessment and the so-called "precautionary principle". This time discrepancies between the two parties concerned meat, which in the production process came into contact with substances that pose a real threat to human life and health. In 1997, the EU introduced a ban on imports of US poultry treated with bactericidal substances, including chlorine-based ones. The EU position on US poultry stemmed from the Regulation (EC) No. 853/2004 of the European Parliament and of the Council of 29 April 2004 laying down specific hygiene rules for food of animal origin. ${ }^{20}$ In 2009 , the US brought a complaint related to poultry to the WTO. The case was registered under reference no. DS398 and is still waiting for its settlement. President D. Trump was personally interested in the matter of restrictions on the export of American poultry to the EU. In March 2018 here quested appropriate action to be taken in this regard by the Secretary of Commerce, W. Ross. The President's personal interest in the matter can be tracked back to 2016 presidential campaign when D. Trump released his famous photo with KFC lunch on board of his private jet. The risk of importing chlorine-treated US poultry was also the subject of lively debate within the British government and among the British public. As a result of Brexit and in view of the conclusion of future US-British free trade agreement, the UK government will have to decide whether it intends to lower its national food safety standards and allow US chlorine-treated poultry into its market. ${ }^{21}$

\section{ii. $\quad$ Spanish olives (2017 - present)}

In addition to traditional trade-distorting measures (quotas, tariffs or their combination - the so-called TRQ), countries can resort to other measures affecting international trade. One of such measures is to subsidize the production and to sell certain product categories below production costs (the so-called dumping). In response to such practices countries may impose anti-dumping duties which are allowed with the WTO system under Article VI of the General Agreement on Tariffs and Trade (GATT) 1994 and special Agreement on implementation of that provision. In 2017, the US administration conducted an investigation as to whether dumping

20 Official Journal of European Communities, L 139/55, 30 April 2004.

21 Too fat to stand and their flesh rots while they're alive, DailyMail.co.uk, 29 July 2009. 
was used in case of Spanish table black olives. The conclusion of the investigation was unfavorable to Spanish and EU producers. According to the outcome of the investigation Spanish olives sold in the US were up to $25 \%$ cheaper than their real market value. Spain is the largest producer of olives in the world. In 2017, the US was a key recipient of Spanish olives (over 24\% of Spanish domestic production was allocated to the US market). As a result of actions of the US administration in the first quarter of 2018 the export of black Spanish olives to the US dropped by as much as $42 \%$ year-to-year. In July 2018 new US regulations with $34 \%$ tariffs on Spanish olives came into force. New tariffs would be imposed for the next 5 years with option of its extension by another 5 . The European Commission and majority of member states have already declared their support for Spain's position in its struggle against the US. The EU is currently examining the case and considering taking adequate retaliatory measures, including the possibility of lodging a complaint to the WTO. It seems Spain can count on the support of all $28 \mathrm{EU}$ agriculture ministers in a dispute with the US. ${ }^{22}$

\section{iii. American soybeans (2018 - present)}

The Chinese-American trade war caused repercussions in US-EU trade relations. The imposition of retaliatory tariffs on US soybeans by the PRC, as to that moment responsible for imports of $50 \%$ of American soybeans, resulted in significant surplus of soybeans on US market. From the moment of imposition of the new Chinese tariffs the administration of President D. Trump strived to guarantee American soybean producers broad access to the EU market. And in fact EU farmers may be particularly interested in increased imports of American soybeans for feed purposes. This interest is definitely supported by the effects of this year's drought in majority of EU member states and heavy losses in feed crops for its livestock. The US and the EU official engaged in direct negotiations on the matter. On 25 July 2018 during three-and-a-half-hour long negotiations in the White House President D. Trump and President J.-C. Juncker agreed that the US will abandon the imposition of duties on cars and auto parts imported from the EU, while in return the EU will undertake to increase imports of US soybeans. By this mean American soybeans became one of the most important bargaining commodity of the same value as steel or cars in bilateral trade. Still commentators draw attention to the fact that if there were no restrictions on imports of US soybeans to the EU, and the market was dominated by private entities, the EU's commitment to increased soybeans imports was purely declarative and resulted from free market conditions rather than political decisions. ${ }^{23}$ In addition it must be highlighted that during the aforementioned meeting both

22 H. von der Burchard, Trump's olive siege of farming fortress Europe, Politico.eu, 24 August 2017.

23 E. Livingstone, K. Oroschakoff, Trump and Juncker: The art of the no-deal, Politico.eu, 26 July 2018. 
leaders agreed also to further de-escalate their trade grievances - if there is progress in negotiations, the US will consider the possibility of withdrawing from customs duties on EU steel, while the EU will reconsider its retaliatory duties on a number of American products (including US orange juice).

Still President Juncker's commitment to increased imports of US soybeans to the EU may conflict with the European Commission's (EC) own plan for the so-called protein self-sufficiency. In November 2018 the EC will publish a strategy on European self-sufficiency with regard to high-protein feeds. Currently, the EU produces only around $5 \%$ of high-protein feed for its farmed animals, the rest must be imported from outside the block. The EC intends to stimulate intra-EU production of high-protein plants, which, unlike American croppers, would not be obtained through genetic modifications. Regarding Poland's position in this matter, it should be pointed out that Poland plans to extend usage of GMO feed only by 2 additional years instead of original 5. Poland will therefore opt for more EU-oriented production rather than US imports. The prohibition on the production, placing on the market and use in animal nutrition of genetically modified feed and genetically modified organisms intended for feed use was introduced under2006 Act on feed. The regulations were to enter into force after two years, i.e. in August 2008, but the deadline was systematically postponed to 2013, then to 2017 and $2019^{24}$.

\section{Conclusions}

The current White House policy regarding international trade is consequential implementation of the President D. Trump's election promises, specifically the implementation of two campaign slogans - the "America First" and "Make America Great Again". The goals of current US administration are to protect the American internal market and simultaneously to gain broader access to third country markets, for instance the EU, for American products. Definitely the views of President D. Trump on international trade do not reflect the classic American conservatism, the so-called "principled conservatism", especially in economic matters. They are, however, a manifestation of traditional American isolationism and economic protectionism. Regardless of signals coming from the US one of the features of current international trade policy of President D. Trump is not to destroy existing international economic and trade institutions, i.e. the WTO, but rather to use them instrumentally in order to pursue its policy goals on selected subject-matters and geographical directions. Although President $\mathrm{D}$. Trump is portrayed as a fierce enemy of the WTO, and even he declares himself as such a person in his public interviews, one would correctly argue that the US would withdraw from its hostile remarks if

24 J.K. Ardanowski, W Polsce nie będzie legalnych upraw roślin GMO, Teraz-srodowisko.pl, 5.09.2018. 
the WTO would be fit to handle US complaints about unfair trade practices of the PRC. In other words, if President D. Trump is served with the draft WTO reform agreement with suitable solutions on international trade then the world trade order, as we know it, will prevail and may even improve in the long run ${ }^{25}$.

The EU and the US have a long history of commercial disputes regarding agri-food products. They may serve as a litmus paper of potential trade war between the two parties. Historically, these disputes concerned, inter alia, hormone-treated beef (1989-2012), bananas (1993-2009) and GMOs (2003-2008). Currently, the US and EU are in dispute over poultry meat treated with bactericidal substances (1997 - present) as well as Spanish olives (2017 - present). Other agri-food products also became "hostages" of the US-EU trade discrepancies regarding other product categories such as steel, cars and their parts. The biggest single challenge in EU-US trade relations is American soybean. As a result of China's retaliatory measures, the US is trying to secure broad access to the EU market for the US soybean producers. However, the American efforts may turn out to be incompatible with the EU plans for its self-sufficiency in high-protein feed.

Bearing the above in mind, it is very unlikely that during the D. Trump's Presidency bilateral discrepancies and misunderstandings between the US and the EU will evolve into an open trade conflict. Both sides seems to avoid such a war as the one unfolding between the US and the PRC. Trilateral talks of the US, Japan and the EU of September 2018 are yet another example of unconditional rapprochement on the part of the EU to the US demands. Therefore the current stance taken by the White House, although very controversial and openly confrontational, pose no real threat to modern international trade order. Such scenario would mean to further inflame increasingly unstable world economy but most importantly to thoughtlessly accept irreversible destruction of historic Transatlantic community of free and democratic nations. From that point there would be no return to bilateral cordial cooperation on variety of areas, from commerce to security. There is too much to lose on the both shores of the Atlantic. So far, the US and the EU were able to settle the majority of its trade disputes, even in the most controversial areas such as GMOs or hormone-treated beef. Even if the White House decides to go along more confrontational path in world affairs, the US Congress would definitely step in and circumvent the powers of the President in order to settle the case with the EU and thus avoid the self-destruction of international trade order as we know it. Therefore current unfavorable trade relations between the US and the EU must be seen as a temporary argument within the family rather than a permanent divorce between the two parties.

25 A plan to save the WTO, ibidem. 


\section{BIBLIOGRAPHY}

[1] A plan to save the WTO, "The Economist", 21-27 July 2018

[2] Agriculture in the Canaries is completely bananas, France24.com, 26 December 2016.

[3] Ardanowski J.K., W Polsce nie będzie legalnych upraw roślin GMO, Teraz-srodowisko.pl, 5.09.2018.

[4] Banana Market Review and Banana Statistics 2012-2013, Report by the Food and Agriculture Organization of the UN, Rome 2014.

[5] Bramwell A., What is Principled Conservatism?, "American Affairs", Spring 2018, vol. II, no. I.

[6] China Urges U.S. to Make 'Right Decision' as \$200B Tariffs Near, Bloomberg.com, 30 August 2018.

[7] EU GMO ban was illegal, WTO rules, Euractive.com, 12 May 2006.

[8] Livingstone E., POLITICO Pro Morning Agri and Food, POLITICO.eu, 24 September 2018.

[9] Micklethwait J., Talev M., Jacobs J., Trump threatens to pull U.S. out of WTO if it doesn't 'shape up', Bloomberg.com, 30 August 2018.

[10] Postell J., Regulation in Early America, "American Affairs", Spring 2018, vol. II, no. I.

[11] Swanson A., Trump Proposes Rejoining Trans-Pacific Partnership, “The New York Times", 12 April 2018.

[12] The transatlantic trade dispute on "hormones" in beef comes to an end, Council of the EU, 9178/12 PRESSE 171, 26 April 2012.

[13] Too fat to stand and their flesh rots while they're alive, DailyMail.co.uk, 29 July 2009.

[14] Trade blockage, “The Economist”, 21-27 July 2018.

[15] United States-Mexico Trade Fact Sheet. Strengthening North American Trade in Agriculture, US Trade Representative's Fact Sheet, 31 August 2018.

[16] USTR Finalizes Tariffs on $\$ 200$ Billion of Chinese Imports in Response to China's Unfair Trade Practices, US Trade Representative's Press Release, 17 September 2018.

[17] USTR Issues Tariffs on Chinese Products in Response to Unfair Trade Practices, US Trade Representative's Press Release, 15 June 2018.

[18] USTR Robert Lighthizer Statement on Agriculture Assistance Against Illegal Trade Retaliation, US Trade Representative's Press Release, 24 July 2018.

[19] Von der Burchard H., Trump's olive siege of farming fortress Europe, POLITICO.eu, 24 August 2017.

[20] Wu M., The 'China Inc.' Challenge to Trade Governance, "Harvard International Law Journal”, Spring 2016, vol. 57, no. 2. 


\section{CZY BIEŻACA POLITYKA HANDLOWA PREZYDENTA DONALDA TRUMPA STANOWI ZAGROŻENIE DLA MIEDZYNARODOWEGO PORZADKU HANDLOWEGO? ANALIZA PRAWNO-POLITYCZNA}

Streszczenie. Celem niniejszego artykułu jest próba odpowiedzi na pytanie, czy obecna polityka handlowa administracji prezydenta Donalda Trumpa, zmierzająca do większego protekcjonizmu i izolacjonizmu $\mathrm{w}$ handlu międzynarodowym, może stanowić zagrożenie dla dotychczasowego międzynarodowego porządku handlowego. Biorąc pod uwagę narastający konflikt handlowy między Stanami Zjednoczonymi a Chińską Republiką Ludową, szczególny nacisk w artykule położono na ryzyko ewentualnego rozwoju analogicznego konfliktu w stosunkach USA z Unią Europejską. Ilustracją rozważań w tym zakresie są historyczne i aktualne spory handlowe wokół produktów rolno-spożywczych, w tym wołowiny poddanej obróbce hormonalnej, bananów, organizmów zmodyfikowanych genetycznie, mięsa drobiowego oczyszczanego substancjami bakteriobójczymi, oliwek hiszpańskich, jak również amerykańskiej soi. Na końcu wyjaśniono, że z wielu powodów perspektywa nowej wojny handlowej między USA a UE jest mało prawdopodobna. Stwierdzono również, że obecne stanowisko Białego Domu w sprawie handlu międzynarodowego, choć bardzo kontrowersyjne i otwarcie konfrontacyjne, nie stanowi realnego zagrożenia dla dotychczasowego międzynarodowego porządku handlowego. Słowa kluczowe: handel międzynarodowy, wojna handlowa, spory, cła, prezydent Donald Trump, Stany Zjednoczone, Unia Europejska, Chińska Republika Ludowa, Światowa Organizacja Handlu, konserwatyzm, produkty rolno-spożywcze. 